\title{
ARTICLES
}

\section{ANIMATED CARTOON SHOWS AND THEIR EFFECTS ON CHILDREN}

\section{Mrs. Baby Uma*I Dr. Ian Clement**}

* Research Scholar, Himalayan University, Itanagar, Arunachal Pradesh, India

** Professor cum Vice-principal, Bhai Gurdas Institute of Nursing, Sangrur, Punjab, India. DOI: http://doi.org/10.47211/trr.2020.v06i01.013

Received $10^{\text {th }}$ May 2020, Accepted $25^{\text {th }}$ May 2020, Available online $25^{\text {th }}$ June 2020.

\section{ABSTRACT}

Everyone loves cartoons. Animated Cartoons are humorous and entertaining. Pre-school Children are attracted more by cartoon teaching than the academic traditional way of learning. Children can learn about the world around us, and other important things with the help of animated cartoons. Cartoons are essential part of every childhood. No one can deny that children can learn a lot from animated cartoons.

Key Words: Animated Cartoon, Cartoon effects on Children.

\section{ABOUT AUTHORS}

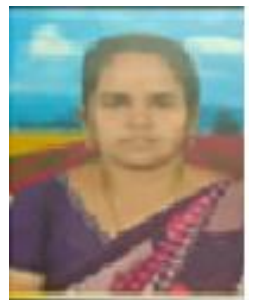

Author Mrs. Baby Uma, K. is a PhD scholar at the Himalayan University at Itanagar, in the Indian state of Arunachal Pradesh. She has attended various national and international conferences and workshops.

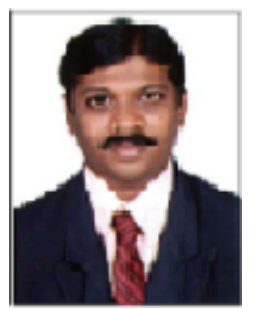

Author Dr. Ian Clement is Professor cum Vice-principal of Bhai Gurdas Institute of Nursing at Sangrur in Punjab, India. He has presented papers in various conferences and seminars. He has many research publications to his Name. 


\section{INTRODUCTION}

The first cartoon produced with sound was Walt Disney's Steamboat Willie, starring Mickey Mouse in 1928. Pre-school children are curious when they watch TV especially cartoons. The word cartoon comes from Italian Word "Caricare" means "to load or exaggerate". It is a drawing that exaggerates the most striking features of its subject to give a comic effect.

\section{ANIMATED CARTOON}

Animated cartoon refers to a motion picture that is made from a series of computer graphics, or photographs of inanimate object such as puppets and that stimulates their movement by slight progressive changes in each frame.

\section{CARTOONS IN INDIA}

- The Banyan Deer (1957), was the first animation movie of India

- Ghayab Aaya was the first animation TV series telecasted in the year of 1986.

- Best and most watched cartoon shows by pre-school children in India: Chhota bheem, Hattori, Motu Patlu, Mr. Bean, Shinchan, Tom and Jerry, Doraemon, Sponge Bob Square Pants, Oggy and cockroaches, Ben 10, road runner, The Simpsons, Mickey Mouse.

\section{EFFECTS OF ANIMATED CARTOON SHOWS ON PRESCHOOLERS}

$84 \%$ of the children's favourite channel is cartoon. Preschool children between 3-6 years of age watch various channels like discovery kids, cartoon network, chutti TV, pogo and nick. Children who watch a favourite cartoon is an effective way to reduce anxiety before surgery by distracting the children (Lee, Kim, 2012).

\section{Positive impacts on watching animated cartoon -}

- Develop logic and reasoning ability, visual and auditory processing and selective attention of the child. Facilitates better retention of information over time among children

- The moving, talking pictures and colourful visuals make learning interesting for children.

- Usage of animated cartoon enhances creativity and imagination

- Use of cartoon material is fun for students. It can be used to entertain the students. Laughing improves blood circulation and release of endorphins and reduces stress

- Animated Cartoon helps the pre-schoolers to learn more about morals

- Helps children learn about different things and helps in language development.

- Animated cartoons can be used to improve cognitive skills.

- Animated cartoon can be used to teach all subjects and to liven up boring subjects.

- Easy to introduce a new topic and allow for warming up of a group

- It can be used to motivate the students while teaching.

- Animated cartoons enable the students to master the curriculum.

Negative impact on cartoons

- Sitting all day in front of the TV watching cartoons,

- Lack of physical activity creates problems with obesity,

- Pushing kids to eat junk foods

- May make them insensitive to others' pain and sorrow

- May show aggressive reactions towards others

- Students may be preoccupied with cartoons too much.

- Watching animated cartoon for long hours can hurt eyes.

Tips for parents to deal with the negative side effects of cartoons on their children:

A child has a blank mind and at this stage starts learning by observing what is going around. Therefore -

> Parents should watch their children what they want to see and know their favourite cartoon.

$>$ Set a rule to limit the time for watching cartoons for 1 hour/day.

$>$ Encourage them to play outdoor games; after that, allow them to sit and watch cartoons.

> Allow the child to watch age-appropriate cartoons/ educational cartoons that do not encourage negative behaviour.

Tell them that the cartoon character is just an imaginary anime.

$>$ Explore informative channels. Encourage the child to watch programmes like learning letters, words, stories and rhymes.

Do not let them eat sitting in front of the TV. 


\section{ARTIC LES}

\section{CONCLUSION}

Animated Cartoon gives a fantasy world to the child and also makes their brain to be creative. May be there are some disadvantages with the cartoon, but, nonetheless, it still used to teach the children. Cartoons prepared for pre-school children are expected to contribute their development, as well as to entertain them. By limiting their screen time, and encouraging them to go outside and play, we can ensure that our children are healthier and happier.

\section{REFERENCES}

1. Habib. K, Solomon. T. (2015). Cartoons effect in changing children mental response and Behaviour, Open journal of Social Sciences.3, 248-264. http://dx.doi.org/10.4236/jss.2015.39033

2. Jeong-woo. L, Kim. D.S, Hyung Sun. L, et al. (2012). Cartoon distraction alleviates anxiety in children during induction of anaesthesia. International Anaesthesia Research Society. 115(5):1168.

3. Rajawat, D. (2017). Cartoon and its effects on socio-emotional development of pre-schoolers. IOSR journal of humanities and social science. Vol 22(1). 13-19.

4. Puneet Sharma (2014). Evolution of Indian animation. http://www.arenamultimedia.com/blog/evolution-of-indian-animation.

5. Rajput, M.K. (2017). Mother's perception about influence of cartoon on child's behaviour. International journal of research and Review.

6. Soumya. A., Gnanajen J., Anitha.R. (2014). A study on parental perception towards children viewing cartoon. International Journal of Scientific Research.

7. Bose. M., Philip. L. (2019). Effects of cartoon shows on children: A study from parent's perspective. International journal of scientific research and review. Vol. 7(3): 977-988. 